\title{
La necesidad del análisis causal frente a la teoría de la imputación objetiva en el derecho penal
}

\author{
José Maria Peláez Mejía*
}

\begin{abstract}
RESUMEN
Con la presente investigación se pretende: (i) delimitar el significado, alcance y los criterios de imputación objetiva; (ii) establecer los ámbitos de competencia o las tareas que le corresponde realizar tanto a la causalidad como la imputación objetiva; $y$ (iii) dar un fundamento filosófico que soporte la exigencia de ambos niveles como elementos necesarios para determinar la responsabilidad penal de un individuo, demostrándose a partir de ello, como tesis principales, que la causalidad y la imputación objetiva cumplen funciones diferentes y necesarias, pues uno es el conector empírico de la realidad naturalística en la que se basa la acción y el resultado; y el otro es el conector normativo. El primero (la causalidad) brinda la materia prima empírica que será analizada y valorada por la segunda para saber si le ha de pertenecer o no a una persona; para saber si, objetivamente (o mejor normativamente) puede serle finalmente atribuida. La segunda, en cambio, valora lo que la primera describe. Asi pues, será puesto de presente que, desde este punto de vista, la imputación objetiva termina siendo un elemento jurídicamente valorativo y prescriptivo, mientras que la causalidad tan solo meramente descriptiva.
\end{abstract}

Imputación objetiva - causalidad - legalidad

\section{The need of the causal analysis against the theory of the objective imputation}

\begin{abstract}
With the following investigation, the intention is to: (i) delimit the meaning, reaches and the criteria of objective imputation; (ii) establish the areas of competences or the tasks that are developed either by the causality or the objective imputation; and (iii) give a philosophical foundation that support the exigences of both levels as necessary elements to determine the criminal liabilty ofan individual, demostrating from it, as main thesis, that the causality and the objective imputation carried out different and necessary functions because one is the empirical
\end{abstract}

* Abogado de la Universidad Libre Seccional Cúcuta. Magíster en Derecho Penal y Magíster en Filosofía del Derecho y Teoría Jurídica de la Universidad Libre de Bogotá. Docente Investigador y Ex-Decano de la Facultad de Derecho y Ciencias Políticas de la Universidad Libre de Cúcuta, Colombia. Correo electrónico: jmpmdeus@gmail.com

Artículo recibido el 7 de abril de 2017 y aceptado para su publicación en este número el 23 de julio de 2018 . 
link of the naturalistic reality in which the action and the result is based on; and the other one is the normative link. The first ( the causality) gives the empirical raw materials that will be analyzed and valued by the second one in order to know if it belongs or not to a person; in order to know, as well, if it is objectively (or better normatively) finally attributed. The second one, on the other hand, values what the first describes. In this way, it will be taken into account, from this point of view that the objective imputation ends up being a juridically valorative and prescriptive, while causality does only in a descriptive way.

$$
\text { Objective imputation - causality - legality }
$$

\section{INTRODUCCIÓN}

$\mathrm{L}$ a existencia de causalidad o nexo causal entre la "conducta" ejecutada por una persona y el ulterior "resultado" producido es un elemento imprescindible de la responsabilidad penal en los delitos de resultado, y aunque está claro que su comprobación es un requisito necesario para considerar a un sujeto como responsable, también es cierto que tal elemento no es suficiente ${ }^{1}$ para lograr dicho cometido, pues adicionalmente es indispensable demostrar: (i) la vinculación jurídica de esa causalidad empírica con su ejecutor mediante un juicio de imputación objetiva que verifique la creación de un riesgo jurídicamente desaprobado y la concreción de este en el resultado; (ii) si dicho comportamiento fue realizado con dolo o al menos con imprudencia pues está proscrita toda forma de responsabilidad objetiva; y, finalmente, (iii) si tal comportamiento fue perpetrado por un sujeto capaz de comprender lo ilícito de sus actos, consciente de la prohibición de tal comportamiento y con la posibilidad de actuar de otra manera; esto es, si el sujeto actuó con culpabilidad ${ }^{2}$. Sin embargo, el verdadero problema surge cuando se buscan delimitar los roles que han de cumplir la imputación objetiva y la causalidad en la teoría del delito, pues pareciera que existe una mezcla entre conceptos ontológicos (relativos al "ser") y normativos (atinentes al "deber ser") evidenciándose que, adicionalmente al peligro de la falacia naturalista, al día de hoy las relaciones entre estos conceptos no han sido dilucidadas por completo o de forma plenamente satisfactoria. Por esta razón, he decidido ensayar desde el seno de la filosofía y la dogmática jurídico-penal una respuesta clara y suficiente para, al menos, los siguientes interrogantes: ¿qué es la causalidad?, y ¿qué aspectos de la atribución de responsabilidad le compete resolver a la

${ }^{1}$ Así por ejemplo: Jaковs, G., Derecho penal parte general. Fundamentos y teoría de la imputación. Marcial Pons, Madrid, 2010, pp. 237; FrISCH, W. La imputación objetiva del resultado. Desarrollo, fundamentos y cuestiones abiertas. Atelier Libros, Barcelona, 2014, pp. 56; Eser, A. y Burkhardt, B. Derecho Penal. Cuestiones fundamentales de la teoría del delito sobre la base de casos de sentencias. Editorial Colex, Madrid, 1995, pp. 104 y ss.

${ }^{2}$ Ver, en torno de estos niveles básicos de imputación (objetiva, subjetiva y personal), a Mir PUIG, S., "Significado y alcance de la imputación objetiva en el Derecho Penal", en Revista Electrónica de Ciencia Penal y Criminología, 2003. Asimismo lo reconoce Eser, A. y Burkhardt, B. Op. cit. pp. 104 y ss. Sin embargo, agregan como primer nivel de imputación la determinación del becho como una "conducta bumana" a partir de la Teoría General de la Acción. 
causalidad y cuáles a la imputación objetiva?, o en otras palabras, ¿será que esta última hace innecesaria la primera?

Para lograr tal cometido, se abordará primero una exploración teórica de la imputación objetiva efectuando, luego de ello, un análisis filosófico de la causalidad y del juicio de atribución normativo con el fin de establecer una clara delimitación de los ámbitos de competencia o tareas que le corresponderían a cada uno de estos elementos. Finalmente, se pasará a extraer como conclusiones las consecuencias que trae consigo el asumir dicha postura para la configuración tanto de la causalidad como de la imputación objetiva.

\section{LA IMPUTACIÓN OBJETIVA: SIGNIFICADO, ALCANCE Y CRITERIOS}

Definir la imputación pareciera ser algo sencillo. Sin embargo, la ambigüedad y vaguedad del lenguaje es hiperbolizada en el campo del Derecho de una forma tal que casi nunca se tiene una respuesta única y concreta acerca de ningún aspecto de las instituciones jurídicas. Empero, se tratará de buscar una salida dilucidando inicialmente la respuesta que cada corriente dogmática le da a la pregunta sobre qué es la imputación objetiva para luego de ello exponer en el acápite final de esta investigación la solución que podría ser considerada como correcta o al menos la más adecuada dentro del todo coherente que conformaría el sistema jurídico-penal. Por consiguiente, comencemos por afirmar que en sus orígenes -con Hegel ${ }^{3}$, Larenz ${ }^{4}$

${ }^{3}$ El principio fundamental de la imputación objetiva, como bien lo pone de presente Yesid Reyes Alvarado, es formulado por Hegel cuando afirma en los parágrafos 115 al 118 de su Filosofía del Derecho que un suceso solo puede atribuírsele a una persona si tal suceso puede llegar a ser considerado como algo suyo. Cfr. Imputación objetiva. Editorial Temis, Bogotá, 1996, p. 49. Así pues, "el derecho de la voluntad es solo reconocer su propio acto, como acción propia y solo ser culpable de lo que ella conoce que de sus presuposiciones hay en su fin; de aquello que de ellas estaba implícito en su propósito. El acto puede ser imputado solo como culpa de la voluntad, como derecho del saber. (...) Las consecuencias, como la imagen que tiene por ánimo el fin de la acción, constituyen 'el suum' (lo inherente a la acción); pero, al mismo tiempo, la acción como fin ubicado en la exterioridad, es entregada a merced de las fuerzas externas, que vinculan a ella algo completamente distinto de lo que ella es por sí, y la arrastran a consecuencias lejanas, extrañas. Es, justamente, un derecho de la voluntad el imputar a sí solamente la primera cosa, porque ella solo está en su propósito”. Ver: Hegel, Guillermo Federico. Filosofía del derecho. Editorial Claridad, 1968, p. 120.

${ }^{4}$ Larenz consideró que a partir de Hegel era posible construir un sistema de imputación teniendo como presupuestos fundamentales el espíritu y la voluntad. Dicho sistema o juicio de imputación consistió básicamente en un razonamiento en el que se establecía si un determinado hecho pertenecía o no al sujeto como obra suya, logrando a partir de ello diferenciar el hecho propio del acontecer fortuito. Esta delimitación podía lograrse mediante la inclusión de la voluntad en el respectivo juicio de carácter teleológico, pues como ella tenía la capacidad de idearse fines y dirigir el curso causal hasta una específica meta, terminaba por dominar la naturaleza y convertía cada hecho en propio (al respecto ver: RojAs Aguirre, L.E. "Lo subjetivo en el juicio de imputación objetiva: ¿Aporía teórica?”, Revista de Derecho: Vol. XXIII-Nº 1-julio 2010). De esta manera, “de la ley se deduce bajo qué condiciones sobreviene una 'responsabilidad por riesgo', qué riesgos especiales ha de imputarse y a quién, cuándo un deber de indemnización se fundamentará solo en el caso de 'culpa' del causante del daño. Pero también la pauta de culpa legal necesita una concretización ulterior, como han mostrado las discusiones sobre todo acerca del concepto de negligencia. El hoy reconocido 'criterio objetivo de negligencia' contiene ya, si bien el legislador lo concibe en principio como una forma de 
y Honig ${ }^{5}$ - la imputación objetiva tuvo como misión determinar cuándo una conducta es obra de una persona o cuándo no; es decir, cuándo o con qué criterios es posible aseverar que un específico comportamiento le pertenece -como obra suya- a un sujeto. Para tales efectos, estos autores utilizaron en esencia el criterio de dominabilidad (previsibilidad y evitabilidad) del resultado asignándole la función de ser un criterio esencial a la hora de establecer la pertenencia de ese resultado al sujeto investigado ${ }^{6}$. Esto no implicó por supuesto la eliminación de la causalidad como elemento del delito, pues, "antes bien, al juicio causal, como juicio ulterior autónomo, se le agrega el de la imputación objetiva, que tiene que revisar la cuestión axiológica, a saber, la significación de la relación causal para el ordenamiento jurídico, medida según parámetros que están dados con el ordenamiento jurídico mismo"7.

De esta manera, es viable afirmar que la imputación objetiva es la hija rebelde de la causalidad, ya que aun cuando nació inicialmente en el seno de la pugna entre teorías causales ${ }^{8}$ ante la insatisfacción que todas ellas dejaban a la hora de brindar un fundamento adecuado, lógico y razonable para resolver una innumerable cantidad de casos difíciles (como los cursos causales irregulares o extraordinarios, la problemática de la causalidad hipotética, la causalidad alternativa, etc.), terminó siendo un elemento adicional de la tipicidad objetiva y no una teoría de la causalidad que superara a sus predecesoras como se esperaba.

No obstante, en torno a las relaciones entre causalidad e imputación objetiva se encuentran al menos las siguientes posturas: (i) aquellos para quienes la imputación objetiva reemplaza completamente la determinación del nexo causal como elemento independiente en la configuración de la tipicidad ${ }^{9}$; (ii) los que afirman que la causalidad como elemento del tipo penal objetivo no ha desaparecido, sino que simplemente se ha integrado

culpa, algunos elementos de una “imputación objetiva”. Larenz, Karl. Metodología de la ciencia del derecho. Ariel Derecho, 1994, p. 466.

5 A diferencia de Larenz, Honig desarrolla un concepto de imputación netamente dogmático y no filosófico, comenzando su análisis con la crisis que sufrían hasta ese momento las diversas teorías de la causalidad.

${ }^{6}$ Específicamente Honig afirmó que "el intervenir en los procesos de la naturaleza conforme a un fin configura la esencia de la conducta humana, al estar objetivamente teñido por un fin es el criterio para la imputabilidad de un resultado y, con ello, también para delimitarlo del suceso casual. Conforme a ello, es imputable aquel resultado que puede ser concebido como propuesto como fin". Honig. R. "Causalidad e imputación objetiva”, en SANCinetTi, M. A. (coord.) Causalidad, riesgo e imputación, Editorial Hammurabi, Buenos Aires, 2009, p. 116.

7 Ídem, p. 111.

${ }^{8}$ Teorías de la causalidad tales como: (i) la teoría de la equivalencia de las condiciones, desarrollada por Glaser, para la cual todas las condiciones del resultado tienen idéntica y equivalente calidad causal derivándose de esta dos teorías correctivas llamadas la fórmula de la conditio sine qua non y la fórmula de la condición adecuada a las leyes de la naturaleza; (ii) la teoría de la causalidad adecuada o de la adecuación que exigía previsibilidad del curso causal para afirmar la existencia del nexo empírico propuesta por Von Kries y Von Bar; y (iii) teoría de la causalidad jurídicamente relevante conforme a la cual solo una condición es causal del resultado si es jurídicamente importante [Mezger].

9 Por ejemplo: Отто, H. “Diagnosis causal e imputación del resultado en el Derecho Penal”, en $L a$ probibición de regreso en el derecho penal, Universidad Externado de Colombia, Bogotá, 1998, pp. 65-92. Asimismo: Bacigalupo Zapater, E. Derecho Penal, Parte General, Editorial Hammurabi, Buenos Aires, 1999, p. 271 
a la imputación objetiva como uno de sus escalones de estructuración internos ${ }^{10}$; (iii) quienes declaran que la causalidad en los delitos de resultado es simplemente un presupuesto necesario y previo a la determinación de la imputación objetiva pero insuficiente para la afirmación del tipo penal objetivo, por lo que su coexistencia en la configuración de este no resultaría problemática, sino por el contrario indefectible ${ }^{11}$; y (iv) los que abogan por la desaparición de la imputación objetiva y el renacimiento de la causalidad como criterio único de atribución utilizando para ello nuevas teorías provenientes de otras disciplinas del conocimiento que permitan determinar el nexo causal, ya que la mayoría de los casos que resuelve la imputación objetiva son en realidad casos propios de la causalidad ${ }^{12}$.

Asimismo, observamos que en lo atinente a la definición, función y ubicación de la imputación objetiva son evidenciables varias posturas -intercambiables-al respecto: en torno a la definición de imputación objetiva tendríamos que esta ha sido conceptuada de seis formas distintas: (i) como un conjunto de criterios, principios ${ }^{13}$ o topoi ${ }^{14}$ útiles para resolver casos o interpretar determinados tipos penales; es decir, simples criterios o métodos de interpretación que delimitan la tipicidad de una conducta ${ }^{15}$; (ii) considerándola

10 Sería la posición mayoritaria según FRISCH, W. La imputación objetiva del resultado. Desarrollo, fundamentos y cuestiones abiertas. Op. cit., p. 52. Asimismo, puede verse esta postura en Roxin, C. Derecho Penal. Parte General. Tomo I: Fundamentos. La Estructura de la Teoría del Delito. Civitas, Madrid, 1997, p. $346 .$, y más recientemente en Imputación objetiva en el Derecho Penal, Griley, Perú, 2012, p. 40. Sin embargo, no queda clara la posición de Roxin sobre si uno de los criterios de imputación objetiva es la causalidad o no, porque en esos textos así lo afirma expresamente, pero luego dice en otras partes de su obra que solamente son criterios de imputación objetiva la creación del riesgo desaprobado, su realización en el resultado y el alcance del tipo penal sin incluir la causalidad. Al respecto, es bastante diciente -lo que parecería ser otra posición-su artículo denominado: La teoría de la imputación objetiva en Roxin, C. Sistema del hecho punible / 1. Acción e imputación objetiva. Hammurabi, Buenos Aires, 2013, p. 259. Expresamente en este sentido: JAKOBs, G. Derecho Penal, Parte General. Fundamentos y teoría de la imputación, Op. cit., p. 226. También: Frister, H. La causalidad de la acción respecto del resultado en SANCINETTI, M. A. Causalidad, riesgo e imputación, Editorial Hammurabi, Buenos Aires, 2009, p. 481. Igualmente Mir Puig, S. Derecho Penal, Parte General, Editorial Reppertor, Barcelona, 2011, p. 260; Vives Anton, T. S. Fundamentos del sistema penal. Acción significativa $y$ derechos constitucionales, Tirant lo Blanch, Valencia, 2011, p. 315; Puppe, I. La imputación del resultado en Derecho Penal, Ara Editores, Perú 2003, p. 27.

${ }^{11}$ Por ejemplo: Rudolphi, H.J. Causalidad e imputación objetiva. Universidad Externado de Colombia, Bogotá, 2006, p. 30; Jescheck, H.H. \& Weigend, T. Tratado de Derecho Penal. Parte General. Editorial Comares, Granada, 2014, p. 295; SAmson, E. Imputación del resultado y riesgo, en SAnCinetTi, M. A. Causalidad, riesgo e imputación. Buenos Aires: Editorial Hammurabi, 2009, p. 383.

${ }^{12}$ Cfr. al respecto: Hilgendorf, E. "Relación de causalidad e imputación objetiva a través del ejemplo de la responsabilidad penal por el producto”. Anuario de Derecho Penal y Ciencias Penales. 2002, 55, 1: 91-108.

${ }^{13}$ Garrido Montt, M. Derecho penal parte general. Tomo II, Editorial Jurídica de Chile, 2003, p. 69.

${ }^{14}$ En sentido: Kaufmann, A. “¿Atribución objetiva” en el delito doloso?”, en Anuario de derecho penal y ciencias penales, ISSN 0210-3001, Tomo 38, Fasc/Mes 3, 1985, pp. 807-827. Acorde con esta perspectiva Puppe, I. Op. cit., p. 27.

${ }^{15}$ Por ejemplo: SAnCinetTi, M. A. "Observaciones sobre la teoría de la imputación objetiva”, en (varios autores) Teoría de la imputación objetiva, Universidad Externado de Colombia, Bogotá, 1998. 
una teoría superadora de las teorías causales ${ }^{16}$ (y en consecuencia de cierta forma una teoría causal evolucionada o mejorada ${ }^{17}$ ); (iii) admitiéndola como un elemento ${ }^{18}$ del tipo penal objetivo al igual lo son la causalidad o el verbo rector; (iv) mostrándola como una teoría sobre las características objetivas generales de un comportamiento imputable ${ }^{19}$ y en consecuencia equivalente a toda la imputación de la parte objetiva del tipo ${ }^{20}$; (v) enmarcándola en un conjunto de presupuestos normativos de la tipicidad no exigidos expresamente por la ley ${ }^{21}$; y finalmente (vi) concluyendo que es una teoría que anticipa juicios de antijuridicidad ${ }^{22}$.

Ya en cuanto a la función de la imputación objetiva se evidencia también multiplicidad de criterios, pues se le han atribuido nueve objetivos diversos: (i) determinar cuándo existe una conexión jurídica entre la acción o conducta y el resultado ${ }^{23}$ (así pues el resultado que se imputa es a la acción, no al tipo penal); (ii) establecer cuándo es posible atribuir (imputar) un resultado (como obra suya) a su autor ${ }^{24}$; (iii) precisar cuándo es viable atribuir (imputar) una acción (como obra suya) a su autor ${ }^{25}$; o en otras palabras sirve para averiguar el significado de los comportamientos ${ }^{26}$ y en últimas saber quién

16 Más o menos cercano a esta opción: Schünemann, B. "Consideraciones sobre la teoría de la imputación objetiva”, en Aspectos puntuales de la dogmática jurídico-penal, Editorial Ibáñez, Bogotá, 2007.

${ }^{17}$ De una u otra forma: Oтto, H. Op. cit., pp. 65-92 y BACigalupo, E. Op. cit., p. 271.

${ }^{18}$ Luzón Peña, D.M. Derecho Penal, Parte General, Editorial B de F, Buenos Aires, 2016, p. 350; Roxin, C. Derecho Penal. Parte General. Tomo I: Fundamentos. La Estructura de la Teoría del Delito. Op. cit. 346 y ss.

${ }^{19}$ Jakobs, G. Derecho Penal, Parte General. Fundamentos y teoría de la imputación. Op. cit., p. 224.

${ }^{20}$ Cancio Melia, M. Conducta de la Víctima e Imputación Objetiva. Universidad Externado de Colombia, Bogotá, 2001, p. 82 Crítico al respecto Mir PuIG, S. Significado y alcance de la imputación objetiva en Derecho penal ya citado.

${ }^{21}$ Gimbernat Ordeig, E. “¿Qué es la imputación objetiva?”, en Estudios penales y criminológicos, ISSN 1137-7550, No 10, 1985-1986, pp. 167-186.

22 Righi, E. Derecho Penal, Parte General. Argentina: Abeledo-Perrot, 2013, p. 177.

${ }^{23}$ Manfred Burgstaller y Eberhard Schmidhäuser seguirían esta postura según la nota a pie de página número 87 de Reyes Alvarado, Y. Imputación objetiva. Op. cit., p. 75. También de una u otra manera FrISCH, W. Comportamiento típico e imputación del resultado. Barcelona: Marcial Pons, 2004, p. 65. Así expresamente por Schünemann, B., ídem, p. 38. Así mismo Cancio Melia, M. Conducta de la Víctima e Imputación Objetiva. Op. cit., pp. 76 y 82. Igualmente, Mir PUIG, S. Significado y alcance de la imputación objetiva en Derecho penal, op. cit., p. 14.

${ }^{24}$ Pareciera ser esta la postura de un amplio sector de la doctrina alemana según nos cuenta FrisCH, W. "La imputación objetiva estado de la cuestión", en (varios autores) Sobre el estado de la teoría del delito (Seminario de la Universitat Pompeu Fabra), Editorial Civitas, Madrid, 2000, p. 31. Así también: Wessels, J. Derecho penal, parte general. Ediciones Depalma, Buenos Aires, 1980, p. 60.

${ }^{25}$ De una u otra manera es esta la perspectiva de Jakobs cuando define la imputación objetiva como una teoría que "se ocupa de la determinación de las propiedades objetivas y generales de un comportamiento imputable”. Derecho Penal, Parte General. Fundamentos y teoría de la imputación. Op. cit. 224. Curiosamente en el mismo artículo MIR PUIG da dos significados a la imputación objetiva y se adhiere a este concepto en Significado y alcance de la imputación objetiva en Derecho penal.

${ }^{26}$ Llamada por JаковS “Teoría del significado del comportamiento”. Cfr. Jakoвs, G. La imputación jurídico-penal y las condiciones de vigencia de la norma, en Gómez-Jara DíEz, C. Teoría de los sistemas y derecho penal. Fundamentos y posibilidades de aplicación. Universidad Externado de Colombia, Bogotá, 2007, p. 214. 
es garante de qué27; (iv) determinar si están vinculadas jurídicamente acción y resultado, y si la totalidad de esa actuación puede serle imputada a una persona como obra suya ${ }^{28}$; (v) atribuirle (imputar) los resultados al tipo penal ${ }^{29}$; (vi) determinar la relevancia jurídica de la relación causal ${ }^{30}$; (vii) atribuir un sentido jurídico-penal específico a los términos legales que expresan la conducta típica ${ }^{31}$, más allá de la simple descripción del verdadero sentido (literal) de dichos términos; (viii) establecer una relación de riesgo entre precisamente el riesgo creado y el resultado causado ${ }^{32}$; y (ix) determinar las características de la conducta típica no expresamente descritas en el texto legal ${ }^{33}$.

Por último, en lo atinente a la ubicación de la imputación objetiva al interior del esquema del delito encontramos cuatro posturas totalmente diversas: (i) en la categoría dogmática de la acción ${ }^{34}$; (ii) en tipo objetivo ${ }^{35}$; (iii) en la antijuridicidad ${ }^{36}$; y (iv) una tesis diferente, según esta, la imputación objetiva carece de ubicación por ser un método interpretativo de los tipos penales ${ }^{37}$.

Ahora bien, respecto de los criterios de atribución normativa aun cuando existe en los autores citados a pie de página un relativo consenso doctrinal al afirmar que la imputación objetiva exige para su configuración la creación de un riesgo jurídicamente desaprobado y la realización de dicho riesgo en el resultado, esa claridad desaparece al momento de desarrollar los niveles de imputación objetiva entrando nuevamente en múltiples divergencias tanto en el contenido de estos como en el número de escaños necesarios para dar por configurada la atribución jurídica requerida. Por consiguiente, es posible encontrar, al menos, 4 posturas ${ }^{38}$ al respecto - sin incluir el problema de la causalidad

${ }^{27}$ Jaковs, G. "La imputación objetiva, especialmente en el ámbito de las instituciones jurídico-penales del "riesgo permitido", la "prohibición de regreso" y el "principio de confianza”", en JakoBs, G. Estudios de Derecho Penal. Editorial Civitas y UAM Editores, Madrid, 1997, p. 211.

${ }^{28}$ Así Reyes Alvarado, Y. Imputación objetiva. Op. cit., p. 75.

${ }^{29}$ Propio del concepto de Roxin, C. Derecho Penal. Parte General. Tomo I: Fundamentos. La Estructura de la Teoría del Delito. Op. cit. Todo el parágrafo 11.

30 Maurach, R. \& Zipf, H. Derecho Penal, Parte General. Tomo I. Editorial Astrea, Buenos Aires, 1994 , p. 317.

31 Así, Mir Puig, S. Op. cit., p. 8.

32 Silva Sánchez, J.M. “Aberratio ictus e imputación objetiva”. En: Anuario de derecho penal y ciencias penales, ISSN 0210-3001, Tomo 37, Fasc/Mes 2, 1984, p. 368.

33 SuÁrez González, C. \& Cancio Meliá, M. "La reformulación de la tipicidad a través de la teoría de la imputación objetiva”, estudio preliminar a: JakoBs, G. La imputación objetiva en el derecho penal. Editorial Civitas, Madrid, 1996.

${ }^{34}$ Así: Maurach, R. \& Zipf, H. Ídem, p. 308. También: Muñoz Conde, F. \& García Arán, M. Derecho Penal, Parte General. Tirant lo Blanch, Valencia, 2012.

35 Se considera la postura mayoritaria seguida por: Roxin, Jakobs, Frisch, Luzón Peña, Mir Puig, Jescheck/Weigend, Gimbernat, Puppe, Rudolphi, Otto, etc.

36 Así Bustos Ramírez, J. "Imputación objetiva. Cuestiones metodológicas y sistemáticas”. En: Bustos /Larrauri. La imputación objetiva. Temis, Bogotá, 1998.

37 Ver notas 31 y 32 .

38 Esto no constituye más que un intento de sistematización, ya que cada autor incluye los niveles que quiere y los agrupa de las formas más diversas. Por ejemplo Jescheck \& Weigend hablan de 7 criterios o grupos de casos de los que algunos niegan la imputación objetiva y otros que sirven para afirmarla; 
que, según se vio líneas atrás, bien puede hacer parte de los niveles de imputación objetiva o estar por fuera de ella-:

- La postura de los tres niveles (por ej. Roxin, Martínez Escamilla ${ }^{39}$ ): Según esta perspectiva, para que exista imputación objetiva se requieren cumplir tres niveles o criterios: a) la creación de un riesgo no permitido; b) la realización del riesgo no permitido; y c) que lo anterior esté cobijado por el alcance del tipo penal ${ }^{40}$.

- La postura de los dos niveles (por ej. Jakobs, Cancio Melia, Bacigalupo): Parte de dos niveles de imputación: a) una imputación objetiva del comportamiento cuyos criterios negativos de atribución más usuales son: el riesgo permitido, el principio de confianza, la prohibición de regreso y las acciones a propio riesgo; y b) la imputación objetiva del resultado cuyos niveles son coincidentes con los incluidos en la realización del riesgo no permitido perteneciente al segundo criterio de la anterior postura.

- La postura del único nivel (por ej. Frisch): Esta vertiente considera que es necesario separar la "conducta típica" de la "imputación objetiva del resultado". Por lo que a la primera pertenece todo lo relativo a la creación del riesgo jurídicamente desaprobado y a la segunda la "relación de riesgo" como auténtico problema de imputación objetiva.

- La postura ecléctica mayoritaria de los grupos de casos (Schünemann, Mir Puig, Rudolphi, Eser/Burkhardt ${ }^{41}$, Stratenwerth ${ }^{42}$, Wessels, Frister, etc.): De conformidad con esta corriente existen varias reglas, normalmente negativas de la imputación objetiva, para resolver cierto grupo de casos que pueden ser reunidos

\footnotetext{
Maurach y Zipf hacen una agrupación amorfa de casos; Luzón Peña referencia 5 criterios fijos (bastante gaseosos por cierto) y dos criterios más aunque solo posibles; Schünemann alude a 4 grupos de casos cada uno compuesto por "subcasos" y reglas particulares de resolución; Gimbernat Ordeig habla de cinco criterios de imputación objetiva 1. El fin de protección de la norma. 2. Exclusión de la imputación objetiva cuando la acción dolosa causante del resultado típico es una objetivamente correcta. 3. El consentimiento de la víctima en el riesgo como factor excluyente de la imputación objetiva. 4. Casos de ausencia (o de presencia) de imputación objetiva cuando entre la acción inicial dolosa o imprudente y el resultado típico final se interpone la conducta, también dolosa o imprudente, de un tercero. 5. Comportamiento alternativo conforme a Derecho vs. teoría del incremento del riesgo; todo esto en el artículo A vueltas con la imputación objetiva, la participación delictiva, la omisión impropia y el Derecho penal de la culpabilidad. ADPCP, VOL. LXVI, 2013; Puppe habla es de reglas generales de imputación las cuales resume en 13 de ellas; otros como Mir Puig o Cancio Melia hablan de la distinción entre los criterios incluidos en la imputación objetiva en sentido amplio (donde introducen los criterios de Jakobs) y la imputación objetiva en sentido estricto o del resultado (donde incorporan los conceptos de Roxin).

${ }^{39}$ Martínez Escamilla, M. La imputación objetiva del resultado, EDERSA, Madrid, 1992.

${ }^{40}$ En España también seguiría esta postura De La Cuesta AguAdo, P.M. La teoría de la imputación objetiva en la teoría del injusto en España. en Roxin, C. La imputación objetiva en el derecho penal. Lima: IDEMSA, 1997 , p. 75.

${ }^{41}$ Eser, A. \& Burkhardt, B. Derecho Penal. Cuestiones fundamentales de la Teoría del Delito sobre la base de casos de sentencias. Op. cit., p. 121.

42 Stratenwerth, G. Derecho Penal. Parte General I. El hecho punible. Thomson, Editorial Aranzadi, S.A., Navarra, 2005, p. 128.
} 
en dos grandes categorías, niveles o exigencias así: a) Exigencia de la creación de un riesgo jurídicamente desaprobado. Reglas: (i) No se imputa la disminución del riesgo; (ii) No se imputan los resultados imprevisibles; (iii) No se imputan los resultados productos de riesgos generales de vida o riesgos permitidos ${ }^{43}$; (iv) No se imputan los resultados producto del obrar irresponsable de la víctima; y (v) No se imputan los resultados producto del obrar autorresponsable de un tercero. $\mathrm{Y}$ b) Exigencia de la realización del riesgo desaprobado en el resultado (relación de riesgo). Reglas: (i) No hay imputación objetiva cuando el riesgo desaprobado creado por el autor no es el que se realiza en el resultado sino otro; (ii) No se imputan resultados o cursos causales que exceden el ámbito o fin de protección de la norma; y (iii) No se imputan los resultados inevitables; es decir, en los casos de comportamientos alternativos conforme a derecho ${ }^{44}$ "el resultado producido no debe imputarse al autor cuando este se habrá producido igualmente en caso de que la conducta del autor hubiera sido ajustada a derecho" 45 .

Teniendo como base la postura mayoritaria referida quizás sea viable concederle a Frisch ${ }^{46}$ la asociación que hace entre la causalidad y la Teoría de la Imputación Objetiva cuando afirma tajantemente que la creación de un riesgo jurídicamente desaprobado esconde tras de sí la Teoría de la Causalidad Adecuada, mientras que la realización del riesgo en el resultado hace lo propio pero con la Teoría de la Causalidad Jurídicamente Relevante, por lo que en últimas el calificativo de "nueva teoría" que se le da a aquella se debería reservar a otras construcciones dogmáticas más honestas que a diferencia de esta no encubran lo que en últimas sería el resultado de un simple agrupamiento de casos en dos niveles cuya idéntica solución ya había sido prevista por antiguas teorías de la causalidad como las referidas ${ }^{47}$. Además, y respecto de esta perspectiva teórica, razón tiene el profesor Cancio Meliá cuando afirma que: "partiendo de una serie de supuestos prácticos -algunos ya tradicionales y otros ideados o recogidos, sobre todo, por Roxin, gran impulsor de la teoría de la imputación objetiva- ha ido construyéndose, prácticamente por sedimentación, capa por capa, un cuerpo de topoi que se agrupa bajo la denominación de Teoría de la Imputación Objetiva" ${ }^{48}$.

Finalmente, en lo relativo al alcance o ámbito de aplicación de la teoría de la imputación objetiva a pesar que en un principio estuvo circunscrita a los delitos de resultado ${ }^{49}$,

43 Aparte de los típicos casos de riesgo permitido suelen incluirse el principio de confianza y la prohibición de regreso. Así por ejemplo, Righi, E. Op. cit., pp. 180 y ss.

${ }^{44}$ En contra los defensores de la denominada teoría del incremento del riesgo.

${ }^{45}$ FrISCH, W. La imputación objetiva estado de la cuestión. Op. cit., p. 30.

${ }^{46}$ Frisch, W. La imputación objetiva del resultado. Desarrollo, fundamentos y cuestiones abiertas. Op. cit., p. 53.

47 En idéntico sentido cfr. Jescheck, H.H. \& Weigend, T. Tratado de Derecho Penal. Parte General. Op. cit., p. 307.

${ }^{48}$ Cancio Meliá, M. Líneas básicas de la Teoría de la Imputación Objetiva. Ediciones Jurídicas Cuyo, Perú, 2001, p. 21.

${ }^{49}$ Solo Roxin, ver obras citadas. 
hoy ya no es así y considera la postura mayoritaria ${ }^{50}$ que ella es aplicable a todos los delitos en general. De esta manera, como argumenta Yesid Reyes Alvarado, "si de acuerdo con lo ya expuesto se entiende correctamente a la imputación objetiva como la teoría que permite establecer lo que para el Derecho Penal es una conducta lesiva de los intereses sociales, es decir, como el núcleo de la acción penalmente relevante, de la que forma parte no solo un resultado, sino, además, el imprescindible aspecto de la creación de un riesgo jurídicamente desaprobado, resulta innegable que la imputación objetiva no debe quedar reducida a los denominados delitos de lesión, y mucho menos a unos determinados tipos de resultado (...)" 51 .

\section{Causalidad E imputación OBjetiva: Fundamentos Filosóficos DE UNA RELACIÓN PROBLEMÁTICA}

\section{Causalidad e imputación objetiva: ¿una falacia naturalista? Una propuesta de clarificación desde la filosofía general}

Mi posición dogmática con relación a la causalidad empírica es que esta se requiere como un elemento constitutivo del tipo penal objetivo, previo y adicional a la imputación objetiva, considerando así que esta última no reemplaza a aquella sino que constituyen elementos de verificación de la tipicidad diversos con distintas finalidades. Así las cosas, para dar sustento a dicha afirmación pasaré a exponer los fundamentos filosóficos y de teoría del derecho que le dan sustento a tal posición, explicando inicialmente el principio de Hume o la falacia naturalista con el objeto de señalar si mi posición viola o no tal constructo filosófico, para luego de ello poner de presente la fragilidad que de todas formas posee el mencionado principio de Hume desde los recientes estudios de la filosofía analítica, con lo que se podrá determinar que, si acepta como válido tal constructo, mi tesis no lo vulneraría de ninguna manera y si se acogen las posturas actuales de la filosofía general tampoco existiría argumento sólido para controvertir la necesidad de la comprobación causal a la hora de atribuir responsabilidad.

De esta manera, comiéncese por decir que Ronald Dworkin en Justicia para erizos resume el principio de Hume [llamado también la falacia naturalista] de la siguiente manera:

“(...) ninguna cantidad de descubrimientos científicos sobre el estado del mundo -ninguna revelación sobre el curso de la historia o la naturaleza última de la materia

50 Schünemann, Mir Puig, Luzón Peña, Martínez Escamilla, Cancio Melia, etc., ver obras citadas. Claramente Righi, E. Op. cit., p. 179.

${ }^{51}$ Reyes Alvarado, Yesid. Anuario de derecho penal y ciencias penales, ISSN 0210-3001, Tomo 45, Fasc/ Mes 3, 1992, págs. 964-965. 
o la verdad sobre la naturaleza humana- puede establecer ninguna conclusión sobre lo que debe ser sin una premisa o supuesto adicional del deber ser" 52 .

Así pues, desde Hume ${ }^{53}$-en el mundo filosófico- y desde Kelsen ${ }^{54}$-en la teoría del derecho-, existe una completa separación entre el mundo fáctico, el de las ciencias empíricas, y el mundo de la cultura donde está lo jurídico, lo ético, lo moral, etc., sintetizándose todo ello en una máxima: a partir del "ser", es decir de lo que "es", no puede derivarse ningún "deber ser" y por tanto postular un imperativo, esto es, un "deber ser" específico, basándose en que así "es" en la naturaleza, constituye una falacia argumentativa, un salto lógico inaceptable y en esencia un error grave de fundamentación. Un ejemplo puede ilustrar bien cuándo se incurre en dicha falacia argumentativa: recientes investigaciones históricas, biológicas y de psicología evolutiva han demostrado que mientras fue aumentando el tamaño del cerebro de los homínidos se privilegió un gasto de energía para este, lo que conllevó a su vez a la disminución significativa de la capacidad muscular y la fuerza física que nuestros ancestros tenían, razón por la que todas las personas deberían únicamente leer y jamás hacer ejercicio corporal, ya que la naturaleza misma nos dice que lo correcto es hacer evolucionar la mente y no el cuerpo. Nótese cómo se intentó derivar una regla de comportamiento y un juicio de valor, un deber ser, a partir de un dato empírico-natural de la evolución humana, es decir, del ser o lo que es. Sin embargo, según el principio de Hume, una cosa no tiene que ver con otra y realizar ese salto argumentativo es lo que constituiría la falacia.

Precisamente los esquemas del delito causalista y finalista fracasaron rotundamente a nivel filosófico, porque el piso argumentativo tenía como base de toda su estructura la derivación de un "deber ser" del sistema del delito y de las normas penales a partir de una específica manera como se hallaba configurada la realidad y la naturaleza. En el caso de los causalistas, quisieron copiar los sistemas de conexión causales y las leyes físicas, químicas, biológicas y naturales existentes en general para la creación de un esquema de la conducta punible que fuera tan exacto como las matemáticas, pero, por diversas razones $^{55}$, el sistema en su estructura original terminó por sucumbir completamente. Por otro lado, los primeros finalistas liderados por el profesor alemán Hans Welzel fundamentaron y derivaron todas las categorías normativas del delito, el "deber ser",

\footnotetext{
${ }^{52}$ Dworkin, R. Justicia para Erizos. Fondo de Cultura Económico, México, 2014, pp. 34.

${ }^{53}$ Hume, D. Tratado de la naturaleza humana. Editorial Porrúa, México, 2005, pp. 396.

${ }^{54}$ Kelsen, H. Teoría pura del derecho. Introducción a la ciencia del derecho. Ediciones Coyoacán, México, 2008 , pp. 15 y ss.

55 Entre las críticas más usuales que se le realizaron tendríamos las siguientes: (i) que no toda acción implica una modificación del mundo exterior; (ii) que omisión no se puede explicar a partir de la simple constatación de la realidad empírica sino a partir de valoraciones y no queda comprendida en el concepto de acción; (iii) que no siempre el tipo puede establecerse con base en criterios solo objetivos y avalorados, pues también allí son descritos elementos normativos y subjetivos; y (iv) que para la verificación de la antijuridicidad no es suficiente la constatación objetiva de esta, pues las causas de justificación exigen un aspecto valorativo y subjetivo. Al respecto puede verse: Agudelo Betancur, Nodier. Curso de derecho penal (Esquemas del Delito). Ediciones Nuevo Foro: 2013, pp. 64 y ss.
} 
de ciertas estructuras lógico-objetivas de naturaleza ontológica que estaban ubicadas en la realidad empírica, o lo que es lo mismo en el reino del "ser", trayendo como consecuencia de ello su desmoronamiento.

Pero no solo se ha cuestionado desde este plano la filosofía welzeniana, sino que como bien lo señala Mir Puig "tanto las corrientes hermenéuticas como las analíticas han abandonado la pretensión de captar esencias propias del ontologismo. De una u otra forma, se reconoce que nuestra aproximación al mundo está fundamentalmente mediada por el lenguaje que utilizamos para referirnos a él. Las palabras no son puros reflejos necesarios de las cosas, sino nuestro modo de ver las cosas. Al dar nombre a una cosa elegimos qué parte de la realidad cabrá dentro de ese nombre. Ni siquiera la realidad física decide antes del lenguaje dónde empieza una cosa y dónde comienza otra: la naturaleza no está dividida en las cosas que nosotros distinguimos mediante palabras. Y el alcance y sentido de las palabras no nos viene impuesto, sino que surge por el acuerdo de los hablantes: es convencional" 56 .

A partir de este análisis podría pensarse que mi posición en torno a la causalidad empírica como un elemento necesario del tipo penal es un error que incurre en la falacia naturalista explicada, ya que pareciera como que si del hecho que existe en el mundo la causalidad como algo empírico y natural, es decir que es así, estuviera derivando el imperativo de que "debe ser" así también en el Derecho Penal y que por lo tanto los legisladores y doctrinantes se encuentran obligados a incluir la causalidad como un elemento del tipo penal. Sin embargo, ello no sería más que un error en la apreciación de mi tesis que puede ser clarificada mediante dos argumentos: (i) que hoy la falacia naturalista no es un concepto rígido y la imbricación hecho/valor, ser/deber ser hace que la dicotomía se desplome o admita al menos una vinculación contingente y casual entre estos conceptos; y (ii) que la causalidad -como hecho empírico- no lo considero un requisito de la tipicidad objetiva porque derive un "deber ser" de un "ser", sino porque derivo ese imperativo, ese "deber ser" de otro "deber ser" y no de un hecho empírico (o un ser) en sí mismo como será demostrado más adelante. En consecuencia, comencemos a darle desarrollo a las premisas o argumentos expuestos.

El primero de ellos consiste en mostrar que la falacia naturalista o el principio de Hume en la filosofía analítica y de la mente contemporáneas, respecto de la dictomía hecho/valor, ser/deber ser, definitivamente se ha desplomado, como nos lo dice Hilary Putnam, o, en palabras de Searle, se ha convertido en una teoría insuficiente para explicar correctamente las diversas realidades del ser humano en las que dichos conceptos se encuentran en constante convergencia como lo sería el caso de los hechos institucionales que ahora explicaré. En relación con Putnam, su análisis se concreta en plantear que gran parte de nuestro vocabulario encargado de describir hechos se encuentra imbricado de usos normativos éticos, morales, jurídicos, estéticos y demás. Por ejemplo: la palabra

${ }^{56}$ Mir PuIG, S. "Límites del normativismo penal", en Derecho Penal del Siglo XX. Cuadernos de Derecho Judicial, Consejo General del Poder Judicial, Escuela Judicial, Madrid, 2007, pp. 51. 
"cruel" tiene usos ${ }^{57}$ diversos de uno y otro lado, pudiendo ser empleado normativamente para emitir un juicio moral que califique a una persona [vgr. Él es una persona cruel] o de manera puramente descriptiva como cuando un historiador asegura que un rey o emperador determinado fue excepcionalmente cruel o que sus crueldades causaron gran cantidad de revoluciones ${ }^{58}$. “ «Cruel» simplemente ignora la presunta dicotomía hecho/ valor y se permite el lujo de ser empleado unas veces para propósitos normativos y otras como término descriptivo (de hecho, lo mismo ocurre con el término 'crimen'). En la literatura filosófica, estos conceptos son llamados a menudo «conceptos éticos densos»" 59 . Esto le permite concluir a lo largo del texto que la dicotomía hecho/valor, entendida como contraposición e imposibilidad de derivación de un "deber ser" a partir de un "ser", no es absoluta aunque sí muy cuestionable, pues su origen histórico y conceptual proviene de "una empobrecida concepción empirista (y más tarde en una igualmente empobrecida concepción lógico-positivista) de los hechos” ${ }^{60}$, debiéndose reconocer que "hechos y valores están «imbricados» hasta la médula", por lo que es necesario aceptar, si no el completo derrumbamiento de esos mundos y la posibilidad de derivar lo que debe ser de lo que es, al menos sí la porosidad de esas dos realidades, dada la evidente comunicación e implicaciones que existen entre lo normativo y lo empírico.

En cuanto a las razones que John Searle esgrime para considerar incorrecta la falacia naturalista, tendríamos que son las siguientes: es posible derivar el "deber ser" a partir del "ser", porque existen múltiples contraejemplos del lenguaje en donde se evidencia sin lugar a dudas que ello es así. De esta manera, como prototipo de lo dicho, tendríamos la falsa dicotomía de enunciados descriptivos utilizados para comunicar lo que "es" versus los enunciados evaluativos empleados para expresar el "deber ser", pues pese a que los defensores del principio de Hume niegan cualquier confusión entre uno y otro se tiene que al proclamar un argumento como válido lo estamos necesariamente evaluando, "y sin embargo el enunciado de que es válido se sigue de ciertos enunciados 'descriptivos' sobre él. Las nociones mismas de lo que es ser un argumento válido, un argumento sólido, o un buen razonamiento, son evaluativas en el sentido relevante porque, por ejemplo, incluyen las nociones de lo que está justificado o se tiene derecho a concluir, dadas ciertas premisas"61. Entonces, veríamos que como la evaluación de validez de un argumento (su debe ser) depende de una comprobación fáctica del mismo (es decir,

57 "Recuérdese que la filosofía analítica a la que nos referimos proviene del segundo Wittgenstein quien en sus Investigaciones filosóficas [Parte I 1945, Parte II 1948-1949] y sus trabajos preparativos tales como las Observaciones filosóficas [1929-1930] y Los cuadernos azul y marrón [1933-1935], planteó que el lenguaje funciona en sus usos. No hay que preguntar, pues, por las significaciones; hay que preguntar por los usos. Pero estos usos son múltiples, variados; no hay propiamente el lenguaje, sino lenguajes, y estos son formas de vida. Lo que llamados 'lenguaje' son 'juegos de lenguaje'. [...] Lo único que hay son 'similaridades', 'aires de familia' que se combinan, intercambian, entrecruzan”. Ferrater, J. Diccionario de filosofía. Tomo IV. Q/Z. Ariel, España, 2012, pp. 3766.

58 Cfr. Putnam, H. El desplome de la dictomía hecho/valor. Paidós, Barcelona, 2004, pp. 49.

59 Ídem, pp. 50.

60 Ídem, pp. 63.

${ }^{61}$ Searle, J. Actos de habla. Cátedra, Madrid, 2009, pp. 178. 
de su ser) resultaría viable asegurar que en estos casos un "deber ser" proviene de un “es”, deduciéndose de ello que la famosa falacia naturalista posee al menos un bache, una excepción significativa o inclusive la ausencia del fundamento necesario para seguir siendo considerada como correcta.

El otro argumento de Searle consiste en mostrar que partiendo de hechos brutos (acontecimientos físicos no construidos socialmente), como por ejemplo el hecho de que una persona emita un conjunto de palabras que podrían ser "por medio de la presente prometo pagarte a ti, Pérez, veinte duros" ${ }^{2}$, es posible derivar un deber ser cuando se invocan hechos institucionales como en este caso sería la promesa, ya que mediante ella se generó una obligación; un deberá pagar lo prometido. Pero todo lo anterior tuvo sentido, explica Searle, gracias a la existencia de una regla constitutiva; es decir, de aquella que no regula simplemente un comportamiento, sino que crea o define nuevas formas de conducta consistente en que "hacer una promesa es asumir una obligación, y esta regla es una regla de significado de la palabra 'descriptiva' "promesa». (...)" ${ }^{\prime \prime 3}$ por ello:

“1. La representación clásica no logra dar cuenta de los hechos institucionales.

2. Los hechos institucionales existen dentro de sistemas de reglas constitutivas.

3. Algunos sistemas de reglas constitutivas incluyen obligaciones, compromisos

y responsabilidades.

4. Dentro de algunos de esos sistemas podemos derivar 'debe' a partir de 'es', siguiendo el modelo de la primera derivación" 64 .

Todo lo expuesto nos muestra que los últimos avances de la filosofía contemporánea han puesto en duda la notoria dicotomía y separación que existía entre el deber ser y el es admitiéndose en general una porosidad del muro que los aislaba, permitiendo en consecuencia una comunicación armónica e inclusive la mutua derivación de uno u otro concepto. En ese orden de ideas, utilizar el principio de Hume y la separación entre los reinos del ser y el debe ser [desarrollado en la teoría jurídica por Kelsen] como premisas básicas para cuestionar la inclusión de la causalidad empírica como un elemento independiente de la imputación objetiva, no tendría hoy por hoy respaldo filosófico alguno, a menos que se deseara ser anacrónico y contraevidente.

Ahora bien, en cuanto al segundo argumento de por qué se debe incluir necesariamente la causalidad como elemento del tipo penal objetivo, nos resulta ineludible aclarar que, si en gracia de discusión deseáramos admitir como correcto y válido el principio de Hume a pesar de las consideraciones precedentes, de todas formas ese "debe ser" no lo estamos derivando de ningún "ser", por ejemplo, la existencia misma de la causalidad en el mundo fáctico, sino de otro "deber ser" cuya ubicación la encontramos en dos fuentes básicas del Derecho: los Tratados Internacionales sobre Derechos Humanos -ratificados

\footnotetext{
62 Ídem, pp. 180.

63 Ídem, pp. 180.

${ }^{64}$ Ídem, pp. 189.
} 
por la mayoría de países del mundo- y en un sin fin de Constituciones Políticas, de donde extraemos dos normas desde las que se evidencia que debe la causalidad empírica o natural constituir uno de los elementos integrantes del tipo penal objetivo. Miremos cuáles son dichas normas.

La primera norma nos dice que solo puede ser declarada responsable una persona y en consecuencia penalizada cuando lleve a cabo la ejecución material de una conducta social externa. [Es lo que se conoce como la exigencia de un Derecho Penal de Acto o Principio del Acto ${ }^{65}$. Consagración positiva: art. 15.1 del Pacto Internacional de Derechos Civiles y Políticos; art. 9 de la Convención Americana de Derechos Humanos; y art. 29 inc. 2 de la Constitución Política Colombiana]. Esta construcción normativa se obtiene al verificar que estos ordenamientos jurídicos de carácter internacional erigen como pilares básicos la dignidad humana, lo que implica la no instrumentalización de su persona sino considerarla un fin de sí mismo y acorde a sus actos, más la regla en la que nadie podrá ser juzgado sino conforme a leyes preexistentes al "acto que se le imputa", presumiéndola inocente hasta que no se la haya declarado judicialmente "culpable" [Art. 29 de la Const. Pol.]. Asimismo, la CADH [art. 9] y el PIDCP [art. 15.1] establecen, como parte del principio de legalidad, que nadie puede ser condenado sino tan solo por la realización de acciones u omisiones consideradas por la ley como delito, con lo que se terminaría ratificando la consagración de un derecho penal de acto y no de autor en dicha normatividad internacional.

La segunda norma establece como requisitos adicionales para que se pueda declarar a una persona como penalmente responsable, la consagración legal previa, estricta y clara de tales acciones u omisiones delictivas, lo que no sería nada distinto que la enunciación normativa del principio de legalidad.

Siguiendo dicha lógica, ¿qué implicaciones tendrían las anteriores normas [deber ser] para la constitución del sistema de delito? Las siguientes:

En virtud del Derecho Penal de Acto solo las conductas humanas activas u omisivas podrían ser penalizadas, descartándose en consecuencia que los simples pensamientos o hechos no humanos, o al menos dirigidos por estos, pudieran constituirse en delito. En tal sentido, la conducta podría definirse como todo comportamiento humano de acción u omisión, manifestado en el mundo exterior y ejecutado por una persona consciente y con voluntariedad; es decir, de forma dominable por ser además previsible y evitable. Ahora bien, en los casos de imprudencia, inclusive en la denominada sin representación, también se cumplen las condiciones de dominabilidad del hecho (consciencia y voluntariedad), por cuanto el sujeto que lleva a cabo la conducta deberá estar ejecutando una actividad controlable por su sistema nervioso central y no meramente periférico, aunque dirigida a causar un resultado diferente del que finalmente ocurra y que termine siendo lesivo de bienes jurídicamente protegidos. En este sentido, si negásemos la voluntad como un componente propio de la definición universal de conducta no podrían diferenciarse

65 Para un mayor desarrollo de este principio puede consultarse: Fernández, J. Derecho penal. Parte General. Principios y categorías dogmáticas. Editorial Ibáñez, Bogotá, 2011, pp. 173 y ss. 
las acciones imprudentes de los simples actos reflejos en los que tan solo existe intervención del sistema nervioso periférico y en los que, por tanto, en realidad la voluntad se haya anulado. En consecuencia, bajo la perspectiva indicada ha de entenderse "voluntad" como algo diferente de "intencionalidad" o "intención”, siendo la ausencia de esta última la caracterización del actuar imprudente, entre otros elementos, y la inexistencia de la primera la negación misma de la configuración de una conducta humana. De esta definición se rescata que toda conducta es un fenómeno físico indiscutible y por más que algunos funcionalistas radicales quieran reducirlo todo a normas incluidas en un sistema autorreferencial que no necesita del mundo exterior, jamás podrá negarse esta base empírica de la que está hecha la conducta ${ }^{66}$.

Ya en cuanto a la consideración de la conducta como un fenómenos físico ello se desprende del hecho que todos sus componentes -según la definición de la misma- resulten ser empíricos y explicables a partir de diversas ciencias experimentales ${ }^{67}$, como la física, la biología, la genética, la medicina y la neurofisiología. De seguro en estos momentos puede llegarse a pensar que este concepto de conducta implica regresar al naturalismo causalista de fines del siglo XIX. Sin embargo, tal idea sería equivocada, ya que una cosa es comprender qué es la conducta empíricamente hablando y otra muy distinta qué es la conducta como elemento del tipo penal, y hasta ahora tan solo hemos explicado qué significa la acción o la inactividad, es decir, el comportamiento humano, desde el punto de vista empírico, con un objetivo: poner de presente que aun cuando el Derecho Penal tome la conducta y la normativice, nunca podrá desconocer que la base sobre la que se construye tal concepto es una base empírica.

Lo anterior se puede entender mejor con una metáfora [: entre 1665 y 1667 el pintor holandés Johannes Vermeer realizó un hermoso cuadro llamado Het meisje met de parel (La joven de la perla o como otros la conocen: La Mona Lisa holandesa); un óleo en pequeño formato de 46,5 x $40 \mathrm{~cm}$. Esta magnífica obra pertenece a un género de pintura propio del Barroco flamenco holandés llamado la tronie, cuya característica es representar retratos en pequeños cuadros. En esencia, los pigmentos utilizados fueron blanco de plomo, amarillo ocre, bermellón, ocre rojo, verde tierra, sombra natural y azul ultramar, cuya paleta reducida y de colores casi puros aunque llenos de múltiples matices, la convierte en una verdadera exquisitez visual. Pues bien, expuesto el ejemplo, es necesario proceder a distinguir la obra de arte como entidad cultural adecuable

${ }^{66}$ Una postura contraria la establece, por ejemplo, Frank BLECKMAnN en su texto Derecho Penal y Teoría de Sistemas cuando afirma que "no existe la acción o el delito en cuanto estructura del ser de la realidad. Solo existe el proceso de una producción social, históricamente variable, de estos fenómenos (sociales, es decir: de sentido) (...) En este sentido, no hay una realidad accesible detrás de la sociedad, sino que la realidad está en las propias operaciones de la sociedad, que crean su propia realidad comunicacional”. En: GómEZJara Díez, Carlos (Coordinador). Teoría de sistemas y derecho penal. Fundamentos y posibilidades de aplicación. Universidad Externado: 2007, pp. 393-394.

67 Acerca de la causalidad en la física moderna puede consultarse: ArANA, J. "El problema de la causalidad en la mecánica cuántica”. Revista de Filosofía Eikasi, marzo, 2012. Y en lo relativo a la perspectiva filosófica: Bueno, G. En torno a la doctrina filosófica de la causalidad. Revista Meta, Congreso sobre la filosofía de Gustavo Bueno (enero 1989), Editorial Complutense 1992. 
a una época, una corriente y un género pictórico, de su composición empírica como lo serían sus dimensiones, el lienzo empleado y los 7 colores utilizados con sus composiciones químicas. Sin embargo, aun cuando son cosas distintas imposible resulta negar la evidencia de una imbricación mutua, porque no podría existir el hecho institucional del arte -y en específico de esa obra de arte- sin el hecho bruto o la base empírica que la acompaña. De esta manera, sería absurdo que un purista del arte, un normativista estético, asegurara que los juicios de valor son un mundo aparte que no necesita tener en cuenta la realidad empírica porque como bien lo sabemos si físicamente no hubiese existido el lienzo y los colores, pues tampoco habría existido la obra de arte. Hagamos entonces la metáfora: la conducta es como el lienzo y la paleta de colores que una vez tipificada se convierte en algo más allá de una realidad física; esto es, en una realidad institucional o jurídica, de la misma manera que en la cultura, el lienzo y la paleta de colores se transformaron en una obra de arte.

Una conducta en su pureza es un fenómeno físico y una vez tipificado no deja de ser tal entidad, ya que al plasmarse en una ley como algo prohibido o castigable tan solo se están seleccionando, de todos los fenómenos físicos existentes, es decir, de todas las conductas, unos cuantos comportamientos de acción o inactividad, en virtud de: (i) el significado que en sí mismos tengan ellos en la realidad institucional, como ocurre con los delitos de mera conducta, v.gr. la injuria o la concusión; y (ii) en virtud de las transformaciones que esas conductas generen en la realidad física o institucional como ocurre con todos los delitos de resultado, v.gr. el homicidio o el aborto. Y precisamente esas dos razones para la tipificación o selección de determinadas conductas bajo el cáliz de prohibidas -según el caso-, junto con las otras como la lesividad o la exclusiva protección de bienes jurídicos quedarán incluidas en los tipos penales como características encargadas de definir y enmarcar qué acciones u omisiones están penalizadas.

Al final de todo esto queda una conducta típica que por ser típica tiene unas características normativas muy específicas que la individualizan y la distinguen de cualquier otra clase de acción u omisión, pero también un fenómeno físico, debido a que lo que se tipificó no fue una ficción o una quimera, sino una realidad empírica completamente verificable, tal y como cuando se hace un cuadro o una pintura en cuyos casos tampoco el artista realiza sus trazos en la nada o en el aire, sino en un lienzo cuya existencia no es ni cercano a lo ficcional.

Por esta razón, y teniendo en cuenta el principio del acto como un imperativo proveniente de los Tratados Internacionales y las diversas constituciones políticas que ordena convertir en punibles únicamente las conductas -y estas como se demostró son fenómenos físicos que al tipificarse no pierden su esencia, aunque se normativicen-deberá cualquier legislación adoptar esa base física de la conducta como uno de los elementos configurativos del delito.

En cuanto al principio de legalidad vemos que este trae como consecuencia el proceso de normativización de la conducta. Asimismo, como derivación de uno de los imperativos que este trae implícito, se deben crear tipos penales o cualquier otro instrumento que sea adecuado para la abstracta, completa, precisa y clara descripción de las conductas que habrán de ser consideradas delitos, con todas sus características específicas. 
Ahora bien, respecto del lugar donde debería ser incluida la conducta -con todos sus elementos físicos y normativos, según el principio de legalidad, es posible concluir que ella debiera aparecer en el tipo penal o en un instrumento análogo de descripción, por ser allí en donde se consagra el contenido de lo delictivo o lo que se considerará prohibido.

De igual manera, por derivación de estos principios de legalidad y de acto, se deduce también la necesidad de tipificación, para los casos en que se requiera, de las transformaciones físicas producto de las conductas seleccionadas como punibles. Es de aclarar asimismo que toda conducta tipificada producirá siempre una transformación en el mundo jurídico (principio de lesividad) y que para conectar esta con aquella se empleará la imputación objetiva. Sin embargo, cuando el tipo penal exija también un resultado empírico se requerirá, para conectar la acción con el resultado, tanto de un nexo empírico llamado causalidad como de uno jurídico llamado imputación objetiva en ese sucesivo orden.

De cada uno de los imperativos anteriormente expuestos se deriva la necesidad de que los tipos penales deban ser de una específica manera, siendo ella la abstracta descripción de conductas humanas bifocales; esto es, estructuralmente empíricas y normativas, sin anulación simultánea de un mundo sobre otro. No obstante, este culto a lo empírico podría asemejarse al que Welzel hizo de las estructuras lógico-objetivas en su radical ontologismo. Sin embargo, ello no es así pues entre esa línea de pensamiento y la acá expuesta existe una gran diferencia: para el genio alemán, la acción y la culpabilidad debían ser elementos de configuración del delito que a su vez debían ser calcados por el legislador, porque como en la realidad física estas estructuras lógico-objetivas existían y eran así, el Derecho Penal tenía la obligación de incluirlas en su haber. Es decir, del ser Welzel derivó cómo el sistema jurídico penal debía ser. En cambio, mi argumentación es diferente: la necesidad de incluir esos conceptos empíricos en un sistema del delito no lo he derivado del ser sino de un deber ser consagrado expresamente en los Tratados Internacionales y las distintas constituciones políticas occidentales. O, en otras palabras, cómo las máximas fuentes del Derecho obligan a que la penalización deba ser de una cierta manera, se deriva que los sistemas jurídicos penales o de delito deban ser de esa manera y no de otra; es decir, empíricos y normativos, razón por la que el mundo del ser ingresa mediante una porosidad que el mismo deber ser originó. Aunque, como se vio líneas atrás, si en últimas hubiésemos derivado el deber ser del ser tampoco se habría incurrido en ningún desfase, pues la falacia naturalista de Hume desde la filosofía analítica contemporánea ha perdido actualidad y se considera esencialmente equivocada.

Ahora bien, llevando las anteriores consideraciones a los temas de causalidad e imputación objetiva tendríamos lo siguiente: la conducta tipificada así como el resultado tipificado son, al tiempo, empíricos y normativos, razón por la que es necesario establecer entre ellos puentes de conexión válidos y pertinentes que abarquen ambos mundos. Son por estas razones que la búsqueda de nexos omnicomprensivos resulta completamente inútil, ya que una conexión meramente ontológica o puramente jurídica termina dejando inconcluso alguno de los presupuestos necesarios para la configuración 
del Delito en cualquier ordenamiento penal. En conclusión, debe entenderse que el Delito no es únicamente onticidad, pero tampoco exclusiva normatividad, constituyendo una y otra ciertos agregados insuficientes a nivel individual pero necesarios en su concurrencia para afirmar la responsabilidad penal, razón por la que -y derivado del análisis realizado líneas atrás- tanto la causalidad como la imputación objetiva son elementos indispensables para establecer el compromiso criminal de un individuo por cuanto solo podrá atribuirse un hecho a una persona como obra suya si y solo si (i) empíricamente se encuentran conectados entre sí el resultado, la conducta y el sujeto a quien se le atribuyen los mismos; y (ii) si a su vez normativamente puede decirse que hay una conexión jurídica que vincule resultado, conducta y ser humano (como partícipe o autor).

A continuación se muestra la notación lógica de lo explicado y su correspondiente representación gráfica para delitos de resultado:

$$
\begin{aligned}
& \text { At }=\text { Abe } \wedge \text { Anc } \\
& \text { Rt }=\text { Rbe } \wedge \text { Rnc } \\
& \text { TO } \leftrightarrow \text { At } \cap \text { Rt }
\end{aligned}
$$

\section{Entonces,}

$$
\mathrm{TO} \leftrightarrow \mathrm{At} \cap \mathrm{Rt}=\mathrm{C}\left[\mathrm{Abe} \cap \mathrm{Rbe}{ }^{\wedge} \mathrm{IO}[\mathrm{Anc} \cap \mathrm{j} \mathrm{Rnc}]\right.
$$

Es decir: la Tipicidad Objetiva [TO] de un hecho se presenta si y solo si $[\leftrightarrow]$ la Acción Típica [At] se encuentra unida, vinculada o conectada [ $\mathrm{f}$ ] a un Resultado Típico [Rt], lo que sería igual $[=]$ a la suma de la Causalidad $[\mathrm{C}]$ - como producto de la Base Empírica de la Acción [Abe] unida empíricamente [ne] a la Base Empírica del Resultado [Rbe] - y [^] la Imputación Objetiva [IO] - como producto de la vinculación jurídica [nj] entre la Acción normativamente caracterizada [Anc] y el Resultado normativamente caracterizado [Rnc].

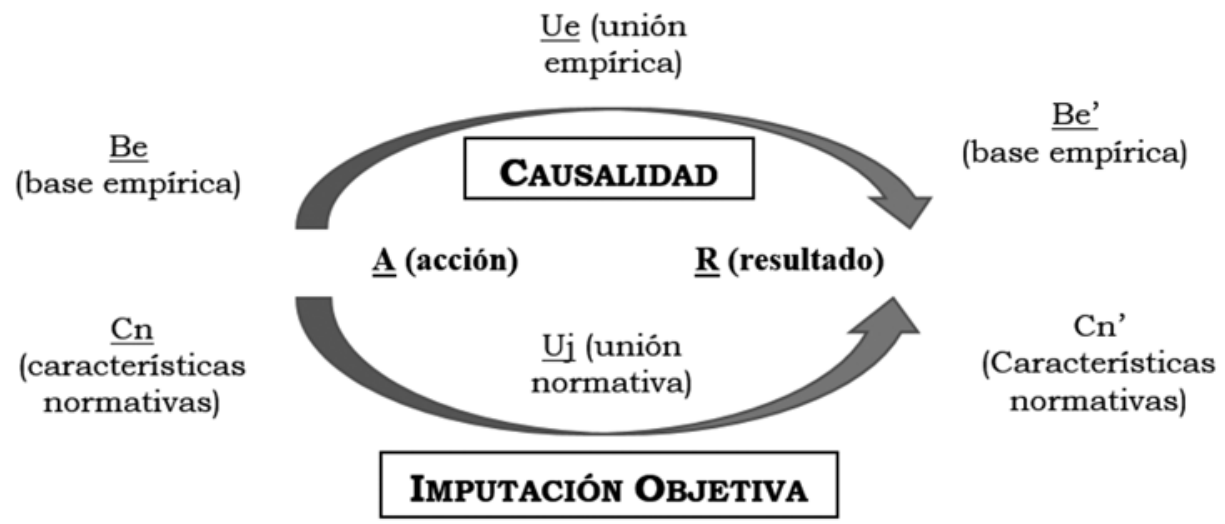




\section{Consecuencias: toma de postura}

En cuanto a la determinación del nexo causal se considera que la teoría correcta es la equivalencia de las condiciones ajustada por el correctivo de la fórmula de la condición adecuada según las leyes de la naturaleza pero enunciada de la siguiente manera: la causalidad es la afirmación de un vínculo material entre dos hechos, uno llamado acción y otro resultado, cuya comprobación (que es un tema ajeno a la teoría del delito y pertenece al derecho probatorio) se hace, en cada caso concreto, a partir de una específica ley de la ciencia que rija para explicar el respectivo fenómeno factual. Igualmente, en torno al concepto de causa tendremos que esta podría ser definida como todo hecho pretérito de carácter empírico-naturalista que constituye la explicación de un resultado, por ser la condición necesaria de este.

Asumir esta perspectiva causal es una ventaja frente a las múltiples objeciones que suelen prosperar respecto de las demás teorías causales, así: (i) El regressus ad infinitum no se presenta, pues cuando la causalidad llega a estudiarse y ya hubo un juicio de adecuación previo que seleccionó una acción y un resultado que tendrán tan solo que ser examinados para verificar si existió una vinculación material; (ii) Los cursos causales hipotéticos en nada afectan la causalidad, pues el hecho está calificado como pretérito y por tanto se evalúa lo que ocurrió y se seleccionó únicamente, no lo que pudo haber ocurrido; (iii) No es tautológica porque con ella no se está estableciendo una ley causal o una explicación anticipada de cada fenómeno, sino unas condiciones que ciertos hechos deberán cumplir para considerarse materialmente conectados; (iv) En los casos de causalidad alternativa esta teoría niega su posibilidad material, pues si tenemos un factor causal que efectivamente ocurrió y a la vez suponemos que otro pudo serlo, pero no lo fue, se estaría subrepticiamente planteando otra forma de causalidad hipotética que no encuadraría en la calificación de hechos pretéritos. Por tanto, causal solo será el hecho pretérito que se constituya en la explicación del otro hecho pretérito; (v) En los casos de causalidad cumulativa la fórmula afirmará la causalidad del hecho pretérito unificado, por cuanto su sumatoria constituye la unidad explicativa del resultado; y (vi) En caso de duda para la determinación de la causalidad por parte de la ciencia, y en consecuencia no se sepa con certeza si un hecho pretérito denominado acción constituye la explicación del otro hecho pretérito llamado resultado, habrá que acudirse al in dubio pro reo y absolver a la persona enjuiciada. Pero esto es un tema de derecho procesal y no de teoría del delito. En esto, precisamente se puede establecer una ventaja frente a la conditio sine qua non, ya que ella quería solucionar problemas jurídicos que hacían parte de la órbita del derecho procesal, a diferencia de mi propuesta que distingue con claridad qué es lo que se debe determinar en el nexo causal y qué no.

Es cierto que con esta teoría muchos de los casos, cuya impunidad intuitiva es evidente, no tendrían tampoco su solución en el escenario de la causalidad, pero es que no la tendrían no porque nuestra propuesta falle, sino porque la justificación de la impunidad o imputación se debe hacer en otro escenario, como por ejemplo en el de la atribución jurídica. Así, en el caso del sobrino malvado que envía a su tío rico a recoger manzanas en mitad de una tormenta vemos que este no encuentra su atipicidad en el nexo 
causal, sino en el nexo jurídico, pues el vínculo empírico sí existe, porque lo que en realidad falta es la imputación objetiva del resultado a su autor y no la causalidad.

En este punto es importante recordar que la imputación objetiva aun cuando en sus inicios pretendió ser una teoría causal que superara a todas sus predecesoras logró independizarse de tal forma que se convirtió en un elemento independiente y adicional a ella que hoy integra el tipo penal objetivo y resulta necesario para afirmar la tipicidad objetiva del comportamiento, pero sin que deba equiparársela con esta. Así pues, comencemos por diferenciar conceptualmente varios significantes y la función que desde mi perspectiva ellos prestan, para evitar de esta manera confusiones inútiles que tan solo distraerían la atención en lo fundamental.

La imputación objetiva es elemento del tipo penal objetivo (de la misma manera que lo son la causalidad, el objeto material, los sujetos, la acción, el resultado, etc.) que exige para su configuración dos niveles: la creación de un riesgo jurídicamente desaprobado (que podría llamarse imputación objetiva de primer nivel o imputación objetiva del comportamiento) y la realización del riesgo en el resultado (cuyo nombre podría ser el de imputación objetiva de segundo nivel o imputación objetiva del resultado). A su vez el tipo penal objetivo sería una de las partes del "tipo penal" integrado por varios elementos, entre los que se encontraría la "imputación objetiva”; mientras que el juicio de tipicidad objetiva lo constituiría la operación mental en donde comparamos los hechos investigados con los elementos del tipo penal objetivo para determinar si existe o no adecuación, subsunción valorativa o equivalencia entre ellos. En caso afirmativo, la consecuencia de dicho juicio de adecuación sería la "tipicidad objetiva" del hecho; y en caso contrario, la "atipicidad objetiva" del mismo. Al respecto es posible evidenciar la existencia de tres juicios de tipicidad objetiva: (i) un juicio de subsunción lógico; (ii) un juicio de imputación fáctica o del hecho empírico; y (iii) un juicio de imputación objetiva, los que serán explicados más adelante.

Desde esta óptica la imputación objetiva buscaría determinar dos cosas: (i) si están vinculadas jurídicamente la acción típica y el resultado típico; y (ii) si la totalidad de esa actuación puede serle imputada a una persona como obra suya. Para hacerlo se vale de los dos niveles antes referidos (como exigencias del mismo): la creación de un riesgo jurídicamente desaprobado y la concreción del riesgo en el resultado como aspectos "positivos" de la imputación objetiva. De esta manera, el riesgo permitido, la prohibición de regreso, el principio de confianza, la falta de lesividad, la no concreción del riesgo desaprobado en el resultado, etc., serían en realidad la faz negativa de cada uno de esos niveles de atribución normativa y no los subniveles de los dos escaños de imputación referidos, por lo que se constituirían en verdaderas causales de ausencia de responsabilidad como factores negativos de imputación objetiva al excluirse alguno de sus niveles. Ejemplificativamente, así como el dolo [compuesto positivamente por dos elementos, uno cognitivo y otro volitivo] posee una contracara o faz negativa llamada "error de tipo invencible", de la misma manera la creación de un riesgo jurídicamente desaprobado como primer nivel de la imputación objetiva tiene -entre muchas otrasuna contracara o faz negativa: el riesgo permitido. En consecuencia, así como aquel (el error de tipo invencible) genera atipicidad subjetiva, también este (el riesgo permitido) 
produce la atipicidad objetiva del hecho y ambos, en últimas, serían entonces ausencias de responsabilidad.

Ya en cuanto a la diferencia de funciones que cumple la imputación objetiva respecto de la causalidad se tiene que, como ya lo dijera desde 1962 Enrique Gimbernat Ordeig, con la claridad mental que lo caracteriza, mediante el problema causal se han intentado dilucidar dos cuestiones: primero, saber qué puede entenderse por causa jurídico-penal, esto es, determinar "cuál es el comportamiento prohibido por la ley" por lo que "la causalidad aparece como el criterio decisivo para delimitar la acción típica de la atípica" 68 . En segundo lugar, con la causalidad también se busca comprobar o constatar la relación o vínculo material que existe entre la acción y el resultado. Sin embargo, la duplicidad de problemas a resolver asignadas a las teorías causales es lo que las convirtió en un verdadero caos, pues erraron al pensar que a la causalidad, que era un tema naturalístico y empírico, le correspondía decidir un tema de atribución y caracterización jurídica, que es normativo ${ }^{69}$. Por ello, siguiendo esta importante diferenciación, establecemos como precisiones conceptuales las siguientes: primero, que la causalidad material no está hecha para determinar cuáles hechos son causas típicas y cuáles no, sino únicamente para decirnos si un hecho específico fue causa o no de otro; y segundo, que el proceso de selección de las acciones y resultados típicos que como hechos serán examinados por la teoría causal para verificar si se encuentran vinculados materialmente, no lo realiza dicha teoría causal, pues para eso no está hecha sino para comprobar las conexiones empíricas, razón por la que la escogencia de un hecho como acción típica y de otro como resultado típico dependerá de un juicio de adecuación que realice el intérprete basado en las caracterizaciones que el tipo penal le ofrezca frente a la realidad presentada, para que después de evaluada y afirmada la causalidad se pase a realizar un juicio de atribución jurídica por medio de la imputación objetiva.

En ese orden de ideas reiteramos que tanto la conducta tipificada como el resultado tipificado tienen la misma dualidad característica de la luz que se comporta a la vez como onda y como partícula, aunque en nuestro caso esa dualidad no es respecto de su comportamiento sino a su esencia: la conducta tipificada y el resultado tipificado son a la vez empíricos y normativos; o en lenguaje de Searle ${ }^{70}$, hechos brutos ${ }^{71}$ y hechos institucionales $^{72}$. Ya en cuanto a la manera de conectar esos mundos se tiene que de forma inicial se debe establecer el nexo empírico mediante el mecanismo que la naturaleza en sus distintas ciencias nos brinda: la causalidad. Y luego se debe tomar ese material

${ }^{68}$ Gimbernat, E. La causalidad en el derecho penal. Anuario de Derecho Penal, Madrid, 1962, fascículo III.

${ }^{69}$ Otra de las problemáticas es la de determinar si la relación de causalidad es un problema fáctico o jurídico, frente a ello acogemos como correcta la posición en donde los enunciados descriptivos son cuestiones de hecho y los valorativos y declarativos cuestiones de derecho. Al respecto ver: KrausE Muñoz, M. S. "La relación de causalidad ¿Questio Facti o Questio Iuris?” Revista de Derecho Vol. XXVII, N 2, diciembre de 2014, pp. 81-103.

${ }^{70}$ Cfr. Searle, J. La construcción de la realidad social. Paidós, España, 1997, p. 49 y ss.

${ }^{71}$ Acontecimientos físicos no construidos socialmente.

${ }^{72}$ Son hechos a merced del acuerdo humano y según la función asignada por los hombres. 
empírico y filtrarlo por lo jurídico para establecer el nexo normativo mediante algunos criterios surgidos hace tiempo y llamados imputación objetiva. Si empíricamente no se diera dicha conexión, es como si, en el caso de un artista dispuesto a pintar nadie le entregara lienzo, pinceles, ni colores; sencillamente ahí todo acabaría. No se podría continuar el juicio de tipicidad y el comportamiento devendría en atípico. Del mismo modo, si la causalidad natural se establece, pero tampoco existe un vínculo jurídico por imposibilidad de imputar objetivamente el resultado o la conducta a su autor y enlazar normativamente de igual forma esos extremos, tampoco podría continuarse con el análisis de lo sucedido y los hechos investigados serían atípicos. Así pues, la causalidad cumple la función de conectar empíricamente los mundos como primer presupuesto de enlace y la imputación objetiva cumple la función de hacer lo mismo, pero normativamente hablando.

De esta manera, es evidente que ambos conceptos (causalidad e imputación objetiva) cumplen funciones diferentes y necesarias, pues uno es el conector empírico de la realidad naturalística en la que se basa la acción y el resultado; y el otro es el conector normativo. El primero brinda la materia prima empírica que será analizada y valorada por la segunda para saber si le ha de pertenecer o no a una persona; para saber si, objetivamente (o mejor normativamente) puede serle finalmente atribuida. La segunda, en cambio, valora lo que la primera describe. Así pues, desde este punto de vista, la imputación objetiva termina siendo un elemento jurídicamente valorativo y prescriptivo, mientras que la causalidad tan solo meramente descriptiva. Por ello, lo correcto es considerar que la causalidad, como elemento del tipo penal independiente de la imputación objetiva, es la afirmación de un vínculo material entre dos hechos, uno llamado acción y otro resultado, cuya comprobación se hace, en cada caso concreto, a partir de una específica ley de la ciencia que rija para explicar el respectivo fenómeno factual.

Finalmente, quisiera terminar esta investigación con una definición de los tres juicios de tipicidad objetiva para evitar también cualquier tipo de nubosidad en torno a mi postura: el juicio de subsunción lógica es aquel que se selecciona de la realidad empírica, en concreto, los hechos cuyas características se adecuan a los sujetos activo y pasivo, la acción típica y el resultado típico, realizando para ello un simple ejercicio de exégesis o comparación entre las cualidades normativas que en abstracto han sido descritas en los distintos elementos del tipo penal objetivo [verbo rector, elementos normativos, etc.] y la realidad empírica. Este primer paso es fundamental, porque la realidad seleccionada es dual: empírica y normativa, y sobre cada uno de esos extremos vendrá a continuación un juicio posterior de valoración, razón por la que a partir de este primer juicio es que se obtiene el objeto de valoración natural y jurídica. Como puede verse, la selección de la acción típica y del resultado típico no se hace en la causalidad ni en la imputación objetiva, y por pensar lo contrario es que tantos desvaríos trajo consigo la construcción de esos dos escalones de análisis. No se puede perder de vista que con este juicio no se busca saber si el hecho ocurrido le pertenece empírica y normativamente al sujeto activo, sino tan solo seleccionar el material con el que en un análisis posterior (causalidad e imputación objetiva, respectivamente) se determinará tal circunstancia. 
En lo atinente al juicio de imputación fáctica o del hecho empírico, una vez seleccionados el sujeto activo y pasivo, así como los hechos constitutivos de acción y resultados típicos se pasa a realizar un juicio de doble atribución:

- Atribución empírica de la conducta: mediante este subnivel se busca afirmar que el hecho pretérito configurativo de la acción típica fue generado por el sujeto activo.

- Causalidad: según se vio desde este subnivel se establece si el hecho pretérito configurativo de la acción típica constituye la explicación del hecho pretérito constitutivo del resultado, perteneciendo también este último, por tanto, al sujeto activo desde un punto de vista meramente empírico.

Por último, se lleva a cabo un juicio de imputación objetiva que consistiría en determinar cuándo la acción y los resultados típicos están conectados jurídicamente y a su vez me pertenecen en virtud de la adecuación de estos a ciertos criterios normativos agrupados en dos grandes niveles: la creación de un riesgo jurídicamente desaprobado y la realización de tal riesgo en el resultado, no olvidando que dicha imputación normativa, aun cuando es necesaria para completar la tipicidad objetiva, no constituye el reemplazo de la causalidad natural ${ }^{73}$, pues tienen fines de atribución diversos e indispensables para satisfacer finalmente la responsabilidad penal. Hechos y Normas conformando una misma cosa (el Delito) y no lo uno ni lo otro sino una nueva categoría que cabalga entre dos mundos, cual lo hizo el lienzo y la pintura al conformar la obra de arte.

\section{BIBLIOGRAFÍA}

Arana, J. "El problema de la causalidad en la mecánica cuántica". Revista de Filosofía Eikasi, Marzo, 2012.

Bacigalupo Zapater, E. Derecho Penal, Parte General, Editorial Hammurabi, Buenos Aires, 1999.

Bleckmann, Frank. "Derecho Penal y Teoría de Sistemas". En: Gómez-Jara Díez, Carlos (Coordinador). Teoría de sistemas y derecho penal. Fundamentos y posibilidades de aplicación. Universidad Externado: 2007, pp. 393-394.

Bueno, G. En torno a la doctrina filosófica de la causalidad. Revista Meta, Congreso sobre la filosofía de Gustavo Bueno (enero 1989), Editorial Complutense 1992.

Bustos Ramírez, J. “Imputación objetiva. Cuestiones metodológicas y sistemáticas”. En: Bustos /Larrauri. La imputación objetiva. Temis, Bogotá, 1998.

Cancio Melia, M. Conducta de la Victima e Imputación Objetiva. Universidad Externado de Colombia, Bogotá, 2001. Del mismo autor: Líneas básicas de la Teoría de la Imputación Objetiva. Ediciones Jurídicas Cuyo, Perú, 2001.

${ }^{73}$ Una posición contraria que aboga por una causalidad de tipo funcional puede verse en: LAMPE, E. "La causalidad y su función jurídico-penal”, en La dogmática jurídico-penal entre la ontología social y el funcionalismo. Editora Jurídica Grijley, Lima 2003, pp. 59-96. 
De la Cuesta Aguado, P.M. "La teoría de la imputación objetiva en la teoría del injusto en España", en Roxin, C. La imputación objetiva en el derecho penal. Lima: IDEMSA, 1997.

Dworkin, R. Justicia para Erizos. Fondo de Cultura Económico, México, 2014.

Eser, A. y Burkhardt, B. Derecho Penal. Cuestiones fundamentales de la teoría del delito sobre la base de casos de sentencias. Editorial Colex, Madrid, 1995.

Fernández Carrasquilla, J. Derecho penal. Parte General. Principios y categorías dogmáticas. Editorial Ibáñez, Bogotá, 2011.

Ferrater, J. Diccionario de filosofía. Tomo IV. Q/Z. Ariel, España, 2012.

Frisch, W. Comportamiento típico e imputación del resultado. Barcelona: Marcial Pons, 2004. Del mismo autor: La imputación objetiva del resultado. Desarrollo, fundamentos y cuestiones abiertas. Atelier Libros, Barcelona, 2014.

Frister, H. "La causalidad de la acción respecto del resultado", en Sancinetti, M. A. Causalidad, riesgo e imputación, Editorial Hammurabi, Buenos Aires, 2009.

Garrido Montt, M. Derecho penal parte general. Tomo II, Editorial Jurídica de Chile, 2003.

Gimbernat Ordeig, E. “QQué es la imputación objetiva?”, en Estudios penales y criminológicos, ISSN 1137-7550, No 10, 1985-1986, pp. 167-186. Del mismo autor: A vueltas con la imputación objetiva, la participación delictiva, la omisión impropia y el Derecho penal de la culpabilidad. ADPCP, VOL. LXVI, 2013 // La causalidad en el derecho penal. Anuario de Derecho Penal, Madrid, 1962, fascículo III.

Hilgendorf, E. "Relación de causalidad e imputación objetiva a través del ejemplo de la responsabilidad penal por el producto". Anuario de Derecho Penal y Ciencias Penales. 2002, 55 , 1: $91-108$.

Honig. R. "Causalidad e imputación objetiva", en Sancinetti, M. A. (coord.) Causalidad, riesgo e imputación, Editorial Hammurabi, Buenos Aires, 2009.

Hume, D. Tratado de la naturaleza humana. Editorial Porrúa, México, 2005.

Jakовs, G. Derecho penal parte general. Fundamentos y teoría de la imputación. Marcial Pons, Madrid, 2010. Del mismo autor: La imputación objetiva, especialmente en el ámbito de las instituciones jurídico-penales del "riesgo permitido", la "probibición de regreso" y el "principio de confianza", en Jakobs, G. Estudios de Derecho Penal. Editorial Civitas y UAM Editores, Madrid, 1997.

Jescheck, H.H. \& Weigend, T. Tratado de Derecho Penal. Parte General. Editorial Comares, Granada, 2014.

Kaufmann, A. “"Atribución objetiva” en el delito doloso?”, en Anuario de derecho penal y ciencias penales, ISSN 0210-3001, Tomo 38, Fasc/Mes 3, 1985, pp. 807-827.

Kelsen, H. Teoría pura del derecho. Introducción a la ciencia del derecho. Ediciones Coyoacán, México, 2008.

Krause Muñoz, M. S. "La relación de causalidad ¿Questio Facti o Questio Iuris?”. Revista de Derecho Vol XXVII, No 2, diciembre de 2014.

LAMPE, E. "La causalidad y su función jurídico-penal", en La dogmática jurídico-penal entre la ontología social y el funcionalismo. Editora Jurídica Grijley, Lima, 2003.

Luzón Peña, D.M. Derecho Penal, Parte General, Editorial B de F, Buenos Aires, 2016.

Martínez Escamilla, M. La imputación objetiva del resultado, EDERSA, Madrid, 1992.

Maurach, R. y Zipf, H. Derecho Penal, Parte General. Tomo I. Editorial Astrea, Buenos Aires, 1994.

Mir Puig, S. "Límites del normativismo penal", en Derecho Penal del Siglo XX. Cuadernos de Derecho Judicial, Consejo General del Poder Judicial, Escuela Judicial, Madrid, 2007.

Muñoz Conde, F. y García Arán, M. Derecho Penal, Parte General. Tirant lo Blanch, Valencia, 2012.

Отто, H. "Diagnosis causal e imputación del resultado en el Derecho Penal”, en La probibición de regreso en el derecho penal, Universidad Externado de Colombia, Bogotá, 1998. 
Puppe, I. La imputación del resultado en Derecho Penal, Ara Editores, Perú, 2003.

Putnam, H. El desplome de la dictomía hecho/valor. Paidós, Barcelona, 2004.

Reyes Alvarado, Y. Imputación objetiva. Editorial Temis, Bogotá, 1996.

Righi, E. Derecho Penal, Parte General. Argentina: Abeledo-Perrot, 2013.

Rojas Aguirre, L.E. "Lo subjetivo en el juicio de imputación objetiva: ¿Aporía teórica?”. Revista de Derecho: Vol. XXIII, N 1 , julio 2010.

Roxin, C. Derecho Penal. Parte General. Tomo I: Fundamentos. La Estructura de la Teoría del Delito. Civitas, Madrid, 1997. Del mismo autor: Imputación objetiva en el Derecho Penal, Griley, Perú, 2012.

Rudolphi, H.J. Causalidad e imputación objetiva. Universidad Externado de Colombia, Bogotá, 2006.

SAmson, E. "Imputación del resultado y riesgo", en Sancinetti, M. A. Causalidad, riesgo e imputación. Buenos Aires: Editorial Hammurabi, 2009.

SAnCinetTi, M. A. “Observaciones sobre la teoría de la imputación objetiva”, en (varios autores) Teoría de la imputación objetiva, Universidad Externado de Colombia, Bogotá, 1998.

SCHünemanN, B. "Consideraciones sobre la teoría de la imputación objetiva”, en Aspectos puntuales de la dogmática jurídico-penal, Editorial Ibáñez, Bogotá, 2007.

SEARLE, J. La construcción de la realidad social. Paidós, España, 1997.

Stratenwerth, G. Derecho Penal. Parte General I. El hecho punible. Thomson, Editorial Aranzadi, S.A., Navarra, 2005.

Silva SÁnChez, J.M. "Aberratio ictus e imputación objetiva”. En: Anuario de derecho penal y ciencias penales, ISSN 0210-3001, Tomo 37, Fasc/Mes 2, 1984.

Vives Anton, T. S. Fundamentos del sistema penal. Acción significativa y derechos constitucionales, Tirant lo Blanch, Valencia, 2011.

Wessels, J. Derecho penal, parte general. Ediciones Depalma, Buenos Aires, 1980. 